\title{
Impact of Sustainable Finance on MSMEs and other Companies to Promote Green Growth and Sustainable Development
}

\author{
Mahesh K. M. ${ }^{1}$, P. S. Aithal ${ }^{2}$ \& Sharma K. R. S. ${ }^{3}$ \\ ${ }^{1}$ Post-Doctoral Research Fellow, College of Management \& Commerce, Srinivas \\ University, Mangalore-575001, India and Principal - SBM Jain Evening College, V.V. \\ Puram, Bangalore-560004, India \\ OrchidID: 0000-0002-7196-7580; Email: km.mahesh@ jaincollege.ac.in \\ ${ }^{2}$ Vice Chancellor, Srinivas University, Mangalore-575001, India. \\ OrchidID: 0000-0002-4691-8736; E-mail: psaithal@gmail.com \\ ${ }^{3}$ Faculty at EWIT, Research Scholar - AIT Bengaluru, India \\ OrchidID: 0000-0001-9559-6633; Email: sharma.krs@gmail.com
}

Subject Area: Business Management.

Type of the Paper: Research Analysis.

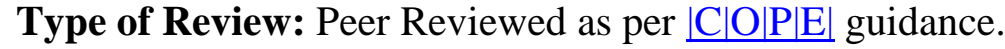

Indexed In: OpenAIRE.

DOI: https://doi.org/10.5281/zenodo.6044523

Google Scholar Citation: IJAEML

\section{How to Cite this Paper:}

Mahesh, K. M., Aithal, P. S., \& Sharma, K. R. S., (2022). Impact of Sustainable Finance on MSMEs and other Companies to Promote Green Growth and Sustainable Development. International Journal of Applied Engineering and Management Letters (IJAEML), 6(1), 60-76. DOI: https://doi.org/10.5281/zenodo.6044523

International Journal of Applied Engineering and Management Letters (IJAEML) A Refereed International Journal of Srinivas University, India.

Crossref DOI : https://doi.org/10.47992/IJAEML.2581.7000.0120

(C) With Authors.

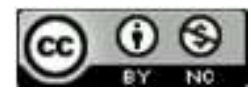

This work is licensed under a Creative Commons Attribution-Non-Commercial 4.0 International License subject to proper citation to the publication source of the work.

Disclaimer: The scholarly papers as reviewed and published by the Srinivas Publications (S.P.), India are the views and opinions of their respective authors and are not the views or opinions of the S.P. The S.P. disclaims of any harm or loss caused due to the published content to any party. 


\title{
Impact of Sustainable Finance on MSMEs and other Companies to Promote Green Growth and Sustainable Development
}

\author{
Mahesh K. M. ${ }^{1}$, P. S. Aithal ${ }^{2}$ \& Sharma K. R. S. ${ }^{3}$ \\ ${ }^{1}$ Post-Doctoral Research Fellow, College of Management \& Commerce, Srinivas \\ University, Mangalore-575001, India and Principal- SBM Jain Evening College, V.V. \\ Puram, Bangalore-560004, India \\ OrchidID: 0000-0002-7196-7580; Email: km.mahesh@ jaincollege.ac.in \\ ${ }^{2}$ Vice Chancellor, Srinivas University, Mangalore-575001, India. \\ OrchidID: 0000-0002-4691-8736; E-mail: psaithal@gmail.com \\ ${ }^{3}$ Faculty at EWIT, Research Scholar - AIT Bengaluru, India \\ OrchidID: 0000-0001-9559-6633; Email: sharma.krs@gmail.com
}

\begin{abstract}
Purpose: Sustainable Finance (SF) contributes to better development and better Finance for Economic growth. Sustainable development is protecting and restoring the ecological system. SIDBI, NITI Aayog, and World Bank facilitate Sustainable Finance to encourage businesses to grow from Small Medium Enterprises to large Industries to make an enormous global impact. As per the World Bank estimate, adversely affect the standard of living of the population and climate change will reduce India's GDP by nearly 3\%. For tracking the climate protection performance of the country, the CCPI tool is used. The Key sustainable finance providers to companies and MSME's are Banks, Corporations, International Financial Institutions, Institutional Investors, International organizations through Financial Instruments Climate Funds, Green Bonds, Impact Finance, Social bonds, Microfinance, SIDBI Sustainable Finance Scheme for funding, NABARD, and Make in India. MSMEs, and SMEs involved in the Projects Solar Power Plants, renewable energy, Green Machinery, Waste Management, Electric Vehicles (EV), Clean Energy, Recycle, Poverty alleviations, and Energy conservation, and India is committed to achieving Net Zero Emissions by 2070. During the Climate summit in Glasgow, India accepted for Five-Point climate 'panchamrit, or pledge' towards climate change and Climate Finance. As per the Environment ministry. India needs $\$ 280$ billion for green infrastructure and the government of India proposed the creation of a Social Stock Exchange, Europe Investment Bank (EIB) with SBI. RBI has considered Green and Sustainable projects should be put under Priority Sector Lending (PSL) to support GE (Green Economy) growth and to meet the SDG (Sustainable Development Goals) and ESG (Economic, Social, Environment) guidelines for fundraising.

Methodology / Design /Approaches: In this article theoretical concepts are used in the analysis of various financing Mechanics for green production and Sustainable development. Findings and results: The effectiveness of sustainable finance or Climate finance required for MSME and Companies for greener production infrastructure and government of India missions on climate Change, Regular to boost the ESG to promote sustainable development and Economic growth.
\end{abstract}

Originality/value: Analysed the various articles and case studies and prepared the model required for sustainable fiancé for green growth in India.

Type of Paper: Research Analysis

Keywords: ESG, Climate Finance, Financial Institutions, Green Bonds, Green Economy, MSME's, RBI, SIDBI, Social Stock Exchange, Sustainable Development Goals (SGS's), $\mathrm{ABCD}$ analysis 


\section{INTRODUCTION :}

Sustainable Finance is one financial instrument to fight climate change and its impacts by regulating emissions and promoting developments in renewable energy and Sustainable development towards ESG-Environmental, Social and Governance. Sustainable development is a concerted effort towards building an inclusive, sustainable and resilient future for people and the planet has three core elements (i) Economic Growth, (ii) Social inclusion and (iii) Environment protection. Socially responsible Investment has already emerged in the late 1960s and 1970s in the US and Europe1980s (Boxenhaum \& Gound,2006) [1]. The concept of the Evergreen Revolution in India was mooted by the Father of the Green revolution M.S. Swaminathan and United Nations Environment Programme (UNEP) has played a leading role in shaping and promoting the green economy for reducing environmental risks. The funding in the area of reduction in carbon emissions, pollution, enhance energy and resource efficiency in the area of clean technologies, renewable energies, water services, green transportation, waste management, green building and sustainable agriculture. Indian economy is one of the fastestgrowing and emerging market economies in the world. As per the Global Climate Risk Index 2021, India stands seventh amongst the most vulnerable countries prone to climate change impact and has incurred losses of USD 69 billion in 2019. Agriculture-related land use accounted for 17\% of global GHG emissions and 16\% of India's GHG emissions from all sectors. India initiative for generating solar energy through International Solar Alliance (ISA) at the Paris climate change summit and with Green Grid Initiative (GGI) led by the UK called One Sun, OneWorld, One Grid (OSOWOG), will draw more investment opportunities for Funding Agency in solar power production.

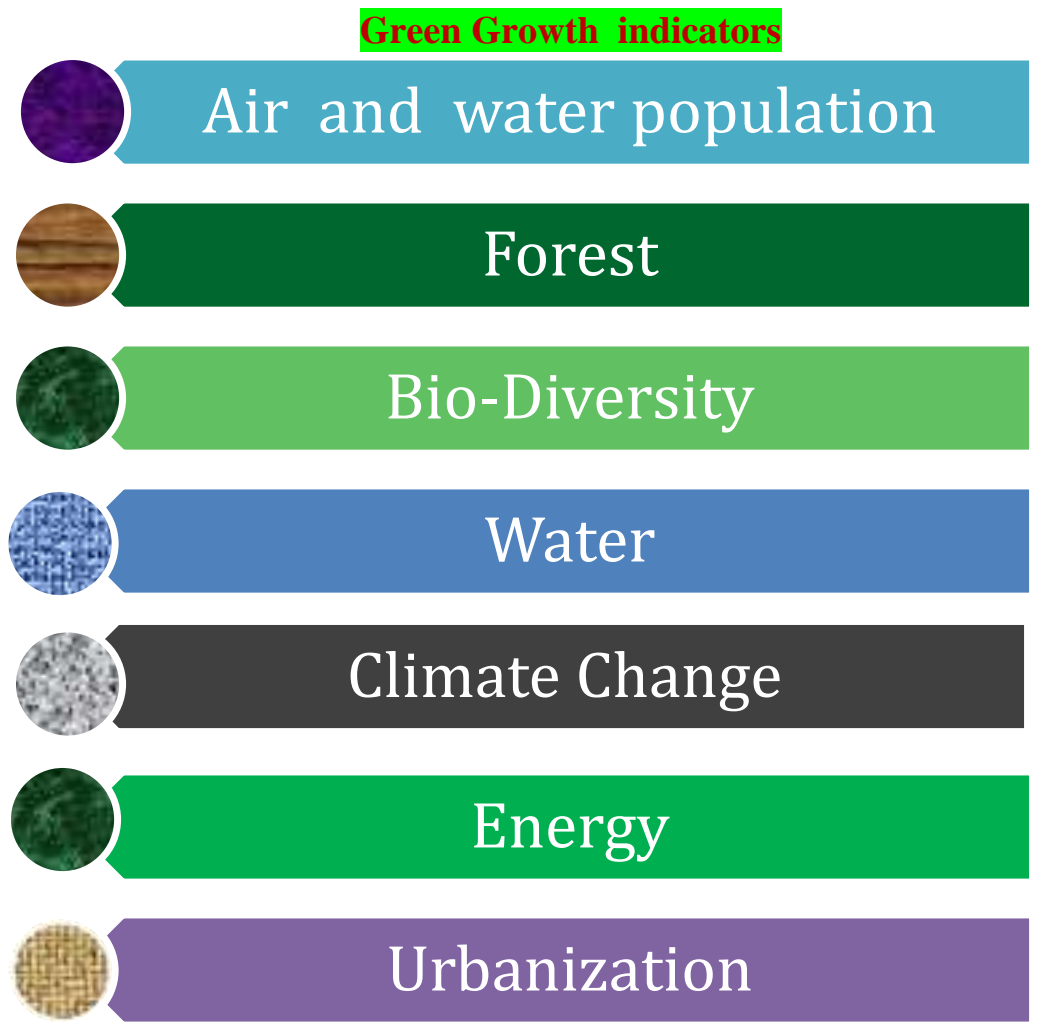

Fig. 1: Green Growth indicators

Source: Global Green Growth institute

New definitions of MSMEs and Companies based on Turnover and Investment Micro-Enterprises Companies with an investment of less than Rs. 1 crore and turnover less than Rs. 5 crores small Enterprises Companies with an investment of less than Rs.10 crore and turnover of Rs. 50 core medium Enterprises Companies with an investment of less than Rs. 50 crore and turnover less than Rs. 250 crore.

\section{RELATED WORKS :}

The author's analysis that the SDGs have set many targets to achieve. Among them are transforming 
public and private activities related to adapting the new business plans, acquiring innovative technology and performing business activities more sustainably. This transformation opens the new kind of opportunities under MSMEs in creating employment opportunities for all under poverty in all regions, be it rural or urban and accomplishes the second SDG, and contributes GAV \& GDP in major ways through green jobs in manufacturing, renewable energy and energy efficiency. Green jobs help in minimizing greenhouse gas emissions, reducing pollution and waste and restoring ecosystems and preserving the environment quality. Ever since 2006-2017, there has been a steady growth in green jobs generation under MSMEs but at a slow pace. The MSMEs have faced a few problems in access to formal credit, difficulty in bringing in equity capital and finance due to the informal nature of the MSMEs. There is a lack of awareness among MSMEs about the government provision regarding MSME loans, lack of availability of labs for product testing, rural broadband and electricity [2].

Table 1: Review of related published work on sustainable finance on MSME

\begin{tabular}{|c|c|c|}
\hline $\begin{array}{l}\text { SI. } \\
\text { No }\end{array}$ & Focus & Authors \& Reference \\
\hline 1 & $\begin{array}{l}\text { The author highlights cooperation with the BRIC framework } \\
\text { and inclusion of developing countries, the infrastructure co- } \\
\text { financing through New Development Bank, India investment } \\
\text { in Africa, Key Human Development Climate change } \\
\text { challenges, Energy equity in sustainable development, } \\
\text { technology skills transfers, techno-economic approach } \\
\text { promoting multi-country projects. It is shown that renewable } \\
\text { energy provides opportunities for Green growth inclusive, } \\
\text { practice and policies are transform the green growth. }\end{array}$ & $\begin{array}{l}\text { Renwick, N, Gu, J \& Xue, L } \\
2018 \text { [3] }\end{array}$ \\
\hline 2 & $\begin{array}{l}\text { The paper highlights in green finance recent trends, } \\
\text { challenges and future opportunities in emerging India. } \\
\text { Regulatory gaps, limited awareness and role of various } \\
\text { banks in green financing including SIDBI and MSMEs } \\
\text { focus on shifting, adopting alternative technologies for } \\
\text { production and process to maximize the energy } \\
\text { conservation }\end{array}$ & $\begin{array}{l}\text { Soundarrajan, P., \& Vivek } \\
\text { N. (2016) [4] }\end{array}$ \\
\hline 3 & $\begin{array}{l}\text { The primary study focuses on } 4 \text { districts to know the MSME } \\
\text { towards sustainable development in availability of } \\
\text { infrastructural facility, financial institution supports } \\
\text { inclusive of entrepreneurial skills, innovation marketing, } \\
\text { opportunities to socially backward classes. The global } \\
\text { challenges are associated with sustainability and highlight } \\
\text { the Environment/Planet, Social Environment/People and } \\
\text { Economic Environment/Profit. }\end{array}$ & Sharma N. (2015) [5] \\
\hline 4 & $\begin{array}{l}\text { The paper highlights sustainable development goals and the } \\
\text { potential of MSMEs in achieving sustainability due to huge } \\
\text { subsidiary organization through the application of policy } \\
\text { approach by the Ministry of MSME towards encouraging } \\
\text { industry-related waste management, lean manufacturing, } \\
\text { credit support, collaboration and awareness programmes for } \\
\text { MSMEs entrepreneurs. The author highlights the MSMEs } \\
\text { promoted and supported through appropriate government } \\
\text { interventions. }\end{array}$ & $\begin{array}{l}\text { Verma, T. L., \& Nema, D. } \\
\text { K. (2019) [6] }\end{array}$ \\
\hline 5 & $\begin{array}{l}\text { The Report highlights the financial assistance for solar } \\
\text { energy support and solar policy for MSMEs and financial } \\
\text { assistance through NABARD, Solar energy Corporation of } \\
\text { India(SECI), National Housing Bank(NHB), IREDAs loan } \\
\text { scheme, skill-building activity connecting solar and rural } \\
\text { population, OPEX MODEL of solar ( Build-own- operate), } \\
\text { competitive market and improving governance system in the } \\
\text { MSMEs. }\end{array}$ & $\begin{array}{l}\text { Acosta, L. A., \& Suresh, S. } \\
\text { (2016) } \\
{[7]}\end{array}$ \\
\hline
\end{tabular}

Mahesh K. M., et al, (2022); www.srinivaspublication.com 


\begin{tabular}{|c|c|c|}
\hline 6 & $\begin{array}{l}\text { In this paper Green Finance: How to Benefit in the Indian } \\
\text { Economy, the author has connected green growth through } \\
\text { products and services in green finance such as green } \\
\text { securitization, green technology leasing, carbon finance, } \\
\text { carbon insurance and corporate finance. Concerning } \\
\text { environmental and economic growth, the author points out } \\
\text { that the MSMEs are neglected due to limited technological } \\
\text { know-how and appropriate financial products. He also } \\
\text { suggests that sustainability measures through the energy } \\
\text { efficiency loan model and training should be provided to the } \\
\text { MSME industry. }\end{array}$ & $\begin{array}{l}\text { Pathak, Devendra and } \\
\text { Srivastava, Vishal and } \\
\text { Sharma, Mohit }(2014) \\
{[8]}\end{array}$ \\
\hline 7 & $\begin{array}{l}\text { In the article sustainability, finance is a new financial vehicle } \\
\text { (ESG funds, Green Bonds) to combat climate change. "The } \\
\text { Global Investment banks, Black Rock. Goldman Sachs, } \\
\text { HSBC, Morgan Stanley, UBS institution" can play a critical } \\
\text { role in sustainability and adapt the global economy in } \\
\text { limiting carbon emissions and the paper outlines SASB - } \\
\text { Sustainability Accounting Standard Board for reporting } \\
\text { ESG from Companies }\end{array}$ & Strauß, N. (2021) [9] \\
\hline 8 & $\begin{array}{l}\text { The Paper analyses } 6 \text { Asia Pacific Central banks of } \\
\text { Bangladesh, India, China, Indonesia, Singapore and Vietnam } \\
\text { for their role in the regulatory framework for Green finance } \\
\text { promoting and sustainable funding options to banks, } \\
\text { insurance companies and refinance in the area of low carbon } \\
\text { industries and financial policy on priority sector lending } \\
\text { (PSL) for banks in allocating funds on social importance. }\end{array}$ & $\begin{array}{l}\text { Durrani A, Rosmin M. } \\
\text { \&Volz U. (2020) [10] }\end{array}$ \\
\hline 9 & $\begin{array}{l}\text { The author analyses the importance of green finance } \\
\text { monetary help for green development and historical } \\
\text { background of green finance, the equator principles, the UN } \\
\text { global compact, green finance products and sustainability } \\
\text { initiatives by RBI, SEBI, The companies Act 2013, IREDA, } \\
\text { Exim Bank, future Scope of green finance in India and } \\
\text { government policies and incentives for adaptation and } \\
\text { mitigation of climate change. }\end{array}$ & $\begin{array}{l}\text { Mohd S. \& Kaushal V. K. } \\
\text { (2018) [11] }\end{array}$ \\
\hline 10 & $\begin{array}{l}\text { Research Article provides insight about green growth } \\
\text { through sustainable technology, innovation } \\
\text { entrepreneurship, government agencies and consumers have } \\
\text { a positive impact on economic growth and more sustainable } \\
\text { society. The paper highlighted the concept of green growth } \\
\text { in the early } 1970 \text { and government policy, collaboration in } \\
\text { technological development has a positive impact in } \\
\text { mitigating climate change. }\end{array}$ & $\begin{array}{l}\text { Fernandes, C. I, Veiga, P. } \\
\text { M., Ferreira, J. J, \& Hughes, } \\
\text { M. (2021) [12] }\end{array}$ \\
\hline
\end{tabular}

\subsection{RESEARCH GAP:}

There are several topics regarding green finance technology, e - policies energy conservation, sustainable growth, sustainable finance etc., which were explained by many authors. The current research article enlighten on sustainable finance in various sectors and also investment made by a European investment bank in India. It also analyses the EV sales and penetration rate that shows the sustainable growth of the country. In this study, to accelerate more Ancillary units of electric chargers to EV sales and green growth more sustainable finance required to MSMEs and company in India will be considered as a research gap. 


\section{OBJECTIVES :}

(1) To Understand the concept of Sustainable finance on MSME and companies concerning green growth.

(2) To know the initiative taken by Government NABARD, SIDBI, RBI and Niti Ayog in Sustainable finance with ECG.

(3) To Analyze the progress of Sustainable finance in India.

(4) To Create a model for MSMEs and Companies Sustainable development.

(5) To apply ABCD analysis constructs for Green Growth and Sustainable development.

\section{NEED OF THE STUDY :}

There is a necessity to provide sustainable finance for green products to protect the environment. The study becomes essential to increase environmental protection, promote economic growth and also social inclusion. This research is very important to enhance the efficient use of renewable resources, water resources, reducing carbon emissions pollution by funding green power production in agriculture, EV, solar and transportation. Contents of this research article explore the idea to reduce the loss of biodiversity, low carbon, increasing afforestation, efficient usage of resources to build the green ecosystem.

\section{SCOPE OF THE STUDY :}

The purview of this area is to know about the various government missions related to sustainable green revolution and also reduce "pollution, social and economic development of the country". It creates an opportunity to protect the environment and promote funding for these green revolutions in several sectors of the economy. This article also covers all various sustainable development funding programmes by NABARD and SIDBI.

\section{RESEARCH METHODOLOGY:}

The methodology used here is purely secondary sources i.e. "Articles, journals, Newspapers and Magazines". Here, a systematic study on the impact of Sustainable Finance on MSMEs and Company to Promote Green Growth and Sustainable development.

\section{THE PROGRESS OF SUSTAINABLE FINANCE IN INDIA :}

\subsection{Role of SIDBI in sustainable development:}

SIDBI has introduced sustainable finance schemes growth and development of MSME. Manufacturing activity and service activity of micro small medium enterprises contribute $6.11 \%$ and 24.63 per cent to the GDP of the country and also it contributes $33.4 \%$ of Indian manufacturing output that helps for the economic growth of the country.

SIDBI provides finance to MEMEs through two major approaches-It it introduced sustainable finance to MSMEs to attain sustainable green projects. The main intention of providing finance for the green revolution is to encourage low carbon, use renewable resources efficiently and also enhance the profitability of MSMEs.

\subsection{Role of NABARD in sustainable development:}

NABARD also made easy accessibility of climate finance for sustainable development and it also provides many e adaptation fund green climate funds and also promoting advanced technology for agriculture increase in green technology for various development projects. One of the schemes introduced by NABARD is APL I the production Linked incentive to promote organic farming efficient use of renewable resources proper management of waste create employment opportunities and so on.

\subsection{RBI and NITI Aayog:}

RBI has made amendments on Priority sector lending and sustainable development in 2012 and 2015 housing, social infrastructure and renewable energy by considering environment risks in assessing agricultural price development. NITI Aayog launched project Shoonya -an initiative to pace of adoption of electric vehicles (EVs) in the urban deliveries segment. EV can lead to the reduction of oil demand, reduction in $\mathrm{CO}_{2}$ and reduction in $\mathrm{GHG}$ emissions 
7.4 Five pledges for a cleaner world by India in CoP-26 -Climate Summit in Glasgow:

Climate summit in Glasgow five pledges are taken that will help to achieve for a cleaner world by India CoP-26. The main goal is to reduce carbon emissions and energy requirements from renewable energy.

Table 2: Five pledges

\begin{tabular}{|l|l|}
\hline 1 & Non-fossil energy capacity will touch $500 \mathrm{GW}$ by 2030 \\
\hline 2 & Reduce the Carbon emissions by 1billion tonnes till 2030 \\
\hline 3 & $50 \%$ energy requirements from renewable energy \\
\hline 4 & Carbon intensity target of 35\% (45\%) \\
\hline 5 & Net-zero by 2070througGreen house gas emissions \\
\hline
\end{tabular}

Source: EIB

\subsection{Rank List of Global Climate Change Performance Index (CCPI):}

The Climate Change Performance Index gave the rank to various countries in that the first 3 places are not awarded to any countries and India got $10^{\text {th }}$ rank. The remaining ranks are listed below.

Table 3: Rank List of Global CCPI

\begin{tabular}{|c|l|}
\hline Rank & \multicolumn{1}{|c|}{ Countries } \\
\hline 1 & None \\
\hline 2 & None \\
\hline 3 & None \\
\hline 4 & Denmark \\
\hline 5 & Sweden \\
\hline 6 & Norway \\
\hline 7 & United Kingdom \\
\hline 8 & Morocco \\
\hline 9 & Chile \\
\hline $\mathbf{1 0}$ & India \\
\hline 13 & Germany \\
\hline 17 & France \\
\hline
\end{tabular}

Source: Times of India November 10,2021

7.6 Sustainable Development Goals and linkage Matrix:

Sustainable development goals and linkage matrix show degree of association with each goal i.e. highest, moderate, lowest and not directly linked.

Table 4: Sustainable Development Goals and linkage Matrix

(Degree of Association: 3 = Highest, 2 Moderate, $1=$ Lowest, and $0=$ Not directly linked)

\begin{tabular}{|l|c|}
\hline \multicolumn{1}{|c|}{ Sustainable Development Goals } & $\begin{array}{c}\text { Degree of Linkage: SDG \& } \\
\text { Renewable Energy }\end{array}$ \\
\hline No Poverty & 0 \\
\hline Zero Hunger & 2 \\
\hline Good Health and Well Being & 1 \\
\hline Quality Education & 0 \\
\hline Gender Equality & 0 \\
\hline Clean Water and Sanitation & 1 \\
\hline Affordable and Clean Energy & 3 \\
\hline Decent Work and Economic Growth & 1 \\
\hline Industry, Innovation and Infrastructure & 2 \\
\hline Reduced inequalities & 0 \\
\hline Sustainable Cities and Communities & 2 \\
\hline Responsible Consumption and Production & 3 \\
\hline
\end{tabular}

Mahesh K. M., et al, (2022); www.srinivaspublication.com 


\begin{tabular}{|l|l|}
\hline Climate Action & 3 \\
\hline Life below Water & 3 \\
\hline Life on Land & 3 \\
\hline Peace, Justice and Strong Institutions & 0 \\
\hline Partnerships for the Goals & 1 \\
\hline
\end{tabular}

Source: YOJANA December 2021

\section{7- Financial Mechanism for Mitigation and adaptation-clean energy and Climate Change and Meaning:}

Financial Mechanism for Mitigation and adaptation-clean energy and Climate Change in various areas and its meanings are shown in the below table 6 .

Table 6: Financial Mechanism for Mitigation and adaptation-clean energy and Climate Change and Meaning

\begin{tabular}{|c|c|c|}
\hline Financial Mechanism & Area & Meaning \\
\hline $\begin{array}{c}\text { Sustainable Finance } \\
\text { India } \\
\text { SIDBI }\end{array}$ & $\begin{array}{l}\text { Integrate Environment, } \\
\text { Social and Governance }\end{array}$ & $\begin{array}{l}\text { Sustainable finance refers to "any } \\
\text { form of financial service integrating } \\
\text { environmental, social and governance } \\
\text { criteria into the business or investment } \\
\text { decisions for the lasting benefit of } \\
\text { both clients and society at large". }\end{array}$ \\
\hline $\begin{array}{c}\text { Climate Finance } \\
\text { India- National } \\
\text { Adaptation Fund for } \\
\text { Climate } \\
\text { Change(NAFCC) } \\
\text { National Clean Energy } \\
\text { Fund } \\
\text { National Adaptation Fund }\end{array}$ & A sustainable low carbon & $\begin{array}{l}\text { Climate Finance is "local, national or } \\
\text { transnational financing-drawn from } \\
\text { public, private and alternative sources } \\
\text { of financing-that seeks to support } \\
\text { mitigation and adaptation actions that } \\
\text { will address climate change." }\end{array}$ \\
\hline Green Finance & $\begin{array}{l}\text { Main focus on diminution in } \\
\text { the area of transportation and } \\
\text { industrial pollution, climate } \\
\text { change, deforestation, carbon } \\
\text { footprint. The area of focus is } \\
\text { "Green Project like } \\
\text { renewable energies, energy } \\
\text { efficiency, Environmental } \\
\text { audits and water sanitation,". }\end{array}$ & $\begin{array}{l}\text { The finance which provides funds to } \\
\text { environmentally sustainable projects } \\
\text { and that should lead to green growth } \\
\text { in the country is called Green finance. }\end{array}$ \\
\hline Green Bonds & $\begin{array}{l}\text { Environmental and Climate } \\
\text { projects. }\end{array}$ & $\begin{array}{l}\text { "Green bonds" and "climate } \\
\text { bonds" are used interchangeably. In } \\
\text { the area of Environmental and } \\
\text { Climate projects raise money as a } \\
\text { fixed-income instrument. }\end{array}$ \\
\hline $\begin{array}{c}\text { ESG Bonds } \\
\text { Investment/Funding }\end{array}$ & ESG Issues & $\begin{array}{l}\text { Portfolio of Equities or bonds which } \\
\text { integrated investment process } \\
\text { includes Environmental, Social and } \\
\text { Governance factors }\end{array}$ \\
\hline
\end{tabular}

7.8 Impact of sustainable finance for climate finance:

$>$ By 2030 Indian green economy will contribute 50 million employment opportunities and by 2070 it will become 15 trillion (according to IBEF).

$>$ According to the assessment of the World Bank India's GDP will be decreased by 3\% due to the variation of climate which has contrary effect effects on the living standards of the people. 
$>$ Sales of the linked overseas bond have increased to 10 billion dollars in this year ( salat, Das 1at times:group.com)

$>100$ million US dollars contributed by SBI, SBI cap ventures and also Neev funds on Indian business which emphasizes the production of electric vehicles, waste management, effective usage of raw materials, and water.

$>$ Sustainable finance helps to accomplish the goals of sustainable development and growth of the country.

> In 2020 CFA institute trust has conducted a survey among 3525 retail investors and 921 institutional investors in 15 major markets comprises India, they found that only $19 \%$ of institutional investors and $10 \%$ of retail investors were investing in the business of environmental, social and governance but remaining $76 \%$ and $69 \%$ of institutional investors and retail investors were having an interest in ESG.

$>$ The major players of sustainable finance are in India are banks, international financial institutions, international organizations such as UN, OECD, G20, EIB, government, institutional investors, operation through CSR initiatives, social stock exchange, international solar alliance with world solar Bank, New Development Banks.

$>$ UNFCCC - The United Nations framework convention on climate change has been set up to provide financial resources to developing countries against various financial risks.

7.9 Share of installed generation capacity of different types of fuel:

There are several types of fields with its share of generation capacity they are nuclear with $1.7 \%$ with $51.9 \%$ share, diesel with $0.1 \%$ share, gas with $6.4 \%$ share, lignite with $1.7 \%$ share, hydro with $12 \%$ share, wind, solar and other RE with $26.4 \%$ share.

$60 \%$ of the share of generation capacity from fossil fuel find $40 \%$ off of share of generation capacity from non-fossil fuel (Economic time -28 November 2021)

\subsection{Government Missions under National Action Plan on Climate Change (NAPCC):}

Understand the Environment \& Ecology through NSM, NMEEE, NWM, GIM, NMSA, NMSKCC, NMSH and NMSHE's missions and its features under National Action Plan on Climate Change

Table 7: Government Missions under National Action Plan on Climate Change and features

\begin{tabular}{|c|c|}
\hline Mission & Features \\
\hline NSM - "National Solar Mission" & $\begin{array}{l}\text { To improve solar energy generation and use } \\
\text { To enhance capacity } 100 \mathrm{GW} \text { by } 2022\end{array}$ \\
\hline $\begin{array}{l}\text { NMEEE - "National Mission for } \\
\text { Enhanced Energy Efficiency" }\end{array}$ & $\begin{array}{l}\text { To build up their regulatory and policy regimes } \\
\text { To achieve fuel savings }\end{array}$ \\
\hline $\begin{array}{l}\text { NWM - "National Water } \\
\text { Mission" }\end{array}$ & $\begin{array}{l}\text { Equitable distribution in the area of conservation of water, } \\
\text { minimizing wastage } \\
\text { Water use efficiency by } 20 \%\end{array}$ \\
\hline GIM - "Green India Mission" & $\begin{array}{l}\text { To enhance carbon sequestration } \\
\text { To the extent the } 5 \text { million hectares forest and tree }\end{array}$ \\
\hline $\begin{array}{l}\text { NMSA - "National Mission for } \\
\text { Sustainable Agriculture" }\end{array}$ & $\begin{array}{l}\text { Nutrient management \& livelihood diversification } \\
\text { New technologies and practices in cultivation }\end{array}$ \\
\hline $\begin{array}{l}\text { NMCC - "National Mission on } \\
\text { Strategic Knowledge for Climate } \\
\text { Change" }\end{array}$ & Providing Strategic knowledge \\
\hline $\begin{array}{l}\text { NMSH - "National Mission on } \\
\text { Sustainable Habitat" }\end{array}$ & $\begin{array}{l}\text { Promote and encourage the use of less polluting vehicles } \\
\text { Promoting technologies and energy conservation practices } \\
\text { Better urban planning-better disaster management }\end{array}$ \\
\hline $\begin{array}{l}\text { NMSHE - "National Mission } \\
\text { for Sustaining the Himalayan } \\
\text { Ecosystem" }\end{array}$ & Significant issues concerning Himalayan Glaciers. \\
\hline
\end{tabular}

Source: Drishti- Environment \& Ecology -Second edition 


\section{ANALYSIS AND INTERPRETATION :}

EV Sales and Penetration rate (2030) includes the annual growth rate and the total number of electric vehicles for said segments covered in the Business India newspaper. To promote green growth Priority sector lending can encourage banks to fast track India's transition to EVs and help achieve 2070 climate goals. It is an opportunity to finance the EVs sector for MSME and companies.

Table 8: EV Sales and Penetration rate 2030

\begin{tabular}{|l|c|c|c|c|c|}
\hline \multicolumn{1}{|c|}{ Vehicle Segments } & $\begin{array}{c}\text { Annual } \\
\text { growth } \\
\text { rate }\end{array}$ & $\begin{array}{c}\text { EV } \\
\text { penetration } \\
\text { rate-2025 }\end{array}$ & $\begin{array}{c}\text { Total No } \\
\text { of EVs - } \\
\mathbf{2 0 2 5}\end{array}$ & $\begin{array}{c}\text { EV } \\
\text { Penetration } \\
\text { Rate 2030 }\end{array}$ & $\begin{array}{c}\text { Total No } \\
\text { of EVs - } \\
\mathbf{2 0 3 0}\end{array}$ \\
\hline E-2W & $5.88 \%$ & $10 \%$ & $1,00,477$ & $30 \%$ & $6,12,353$ \\
\hline E-3W(Passenger/Cargo) & $5.57 \%$ & $40 \%$ & 30,376 & $70 \%$ & $1,15,804$ \\
\hline E-Car(personal) & $3 \%$ & $3 \%$ & 4,519 & $15 \%$ & 42,561 \\
\hline
\end{tabular}

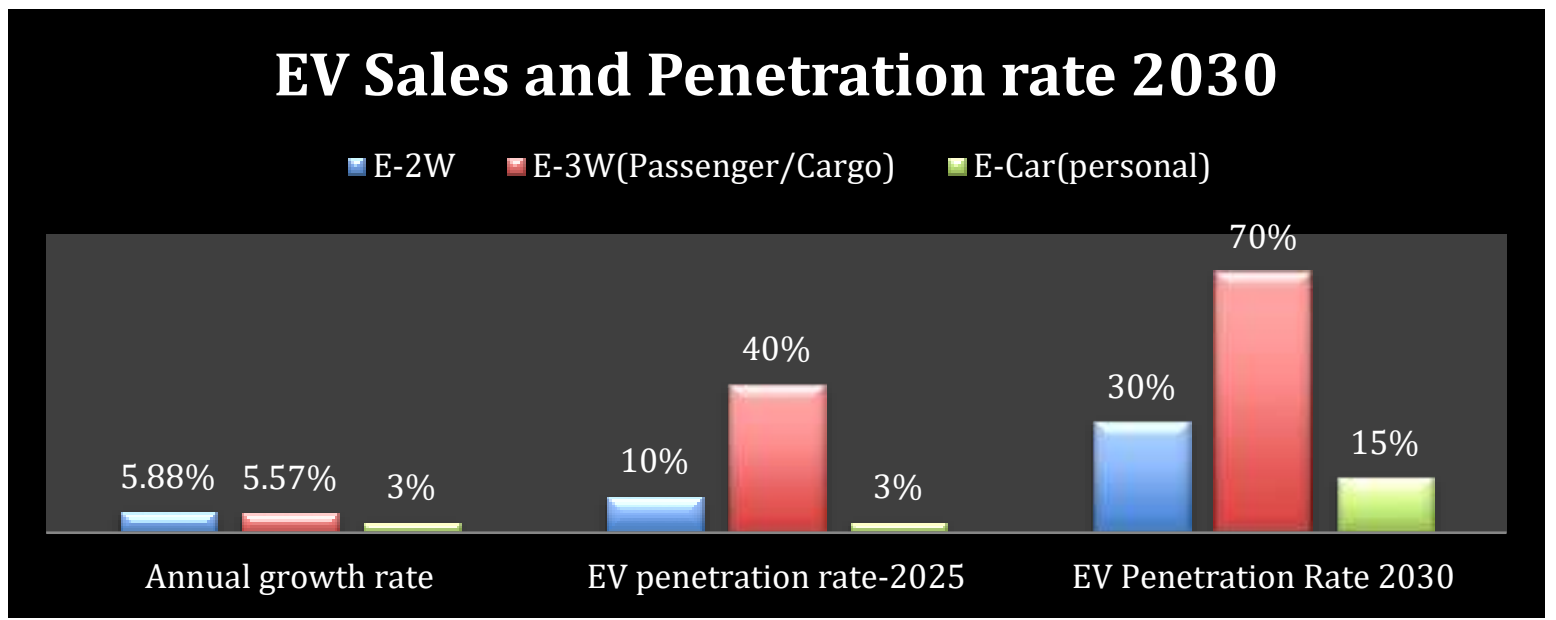

Fig. 1: EV Sales and Penetration rate 2030

As per the report, there is an annual sales growth rate of 5.88 per cent in electrical two-wheeler vehicles, 5.57 per cent in electrical three-wheeler vehicles and 3\% in an electrical car used for personal use. When we forecast sales growth rates in these various segments increased by $10 \%, 40 \%, 3 \%$ in 2025. In the country number of electrical vehicles will be increased due to the proper sustainable financial accessibility for a green revolution in 2025 and also in 2030.

Table 9: Sustainable finance investment needs by Sector

\begin{tabular}{|l|c|}
\hline \multicolumn{1}{|c|}{ Sectors } & $\begin{array}{c}\text { Cumulative Investment needed by 2030 } \\
\text { USD billions }\end{array}$ \\
\hline Energy & $404(2018-30)$ \\
\hline Transport -EVs & $667(2018-30)$ \\
\hline Green Buildings & 1400 \\
\hline Climate-resilient cities & 128 \\
\hline Waste management & $11(2018-30)$ \\
\hline Pollution abatement & 50 \\
\hline Afforestation & 140 \\
\hline Sustainable Agriculture & 194 \\
\hline
\end{tabular}

Source: IFC \& India -UK sustainable Finance Working group-2021 


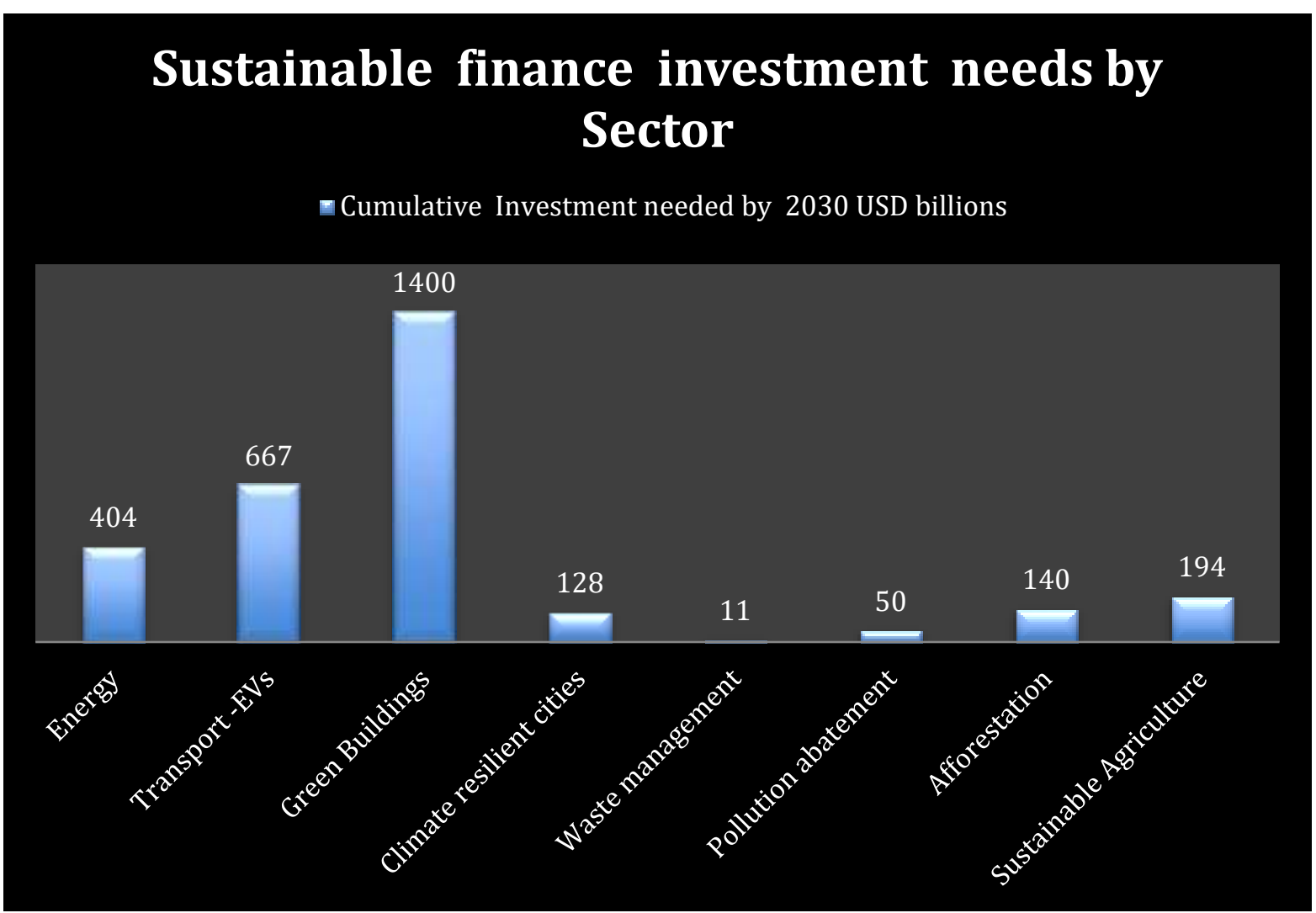

Fig. 2: Sustainable finance investment needs by Sector

From the above graph, it is explained that there is a requirement for proper financial investment for various sectors such as energy, transport, green buildings, climate, resilient cities, waste management, pollution abatement, afforestation, sustainable agriculture. The total highest investment required by 2030 for green building is 1400 USD billion and for transport 667 USD billions. If the target of sustainable finance is achieved by 2030 then there will be constant growth and development in these sectors.

The "European Investment Bank is one of the world's main financers of climate action including Micro-enterprises" The European Investment Bank is the lending arm of the European Union. It is the biggest multilateral financial institution in the world and one of the largest providers of climate finance.

The European investment bank-financed US \$ 4.55 billion in India for various sectors, which boosts climate action including Micro-enterprises.

Table 10: The European Investment Bank (EIB) Financing in India (US \$ 4.55 billion)

\begin{tabular}{|l|c|}
\hline \multicolumn{1}{|c|}{ Sector } & \% Financing \\
\hline Transport & 47.85 \\
\hline Energy & 40.63 \\
\hline Water Sewage & 0.33 \\
\hline Agriculture, Fisheries \& Forestry & 0.09 \\
\hline Credit lines & 8.18 \\
\hline Industry & 2.73 \\
\hline Services & 0.19 \\
\hline
\end{tabular}




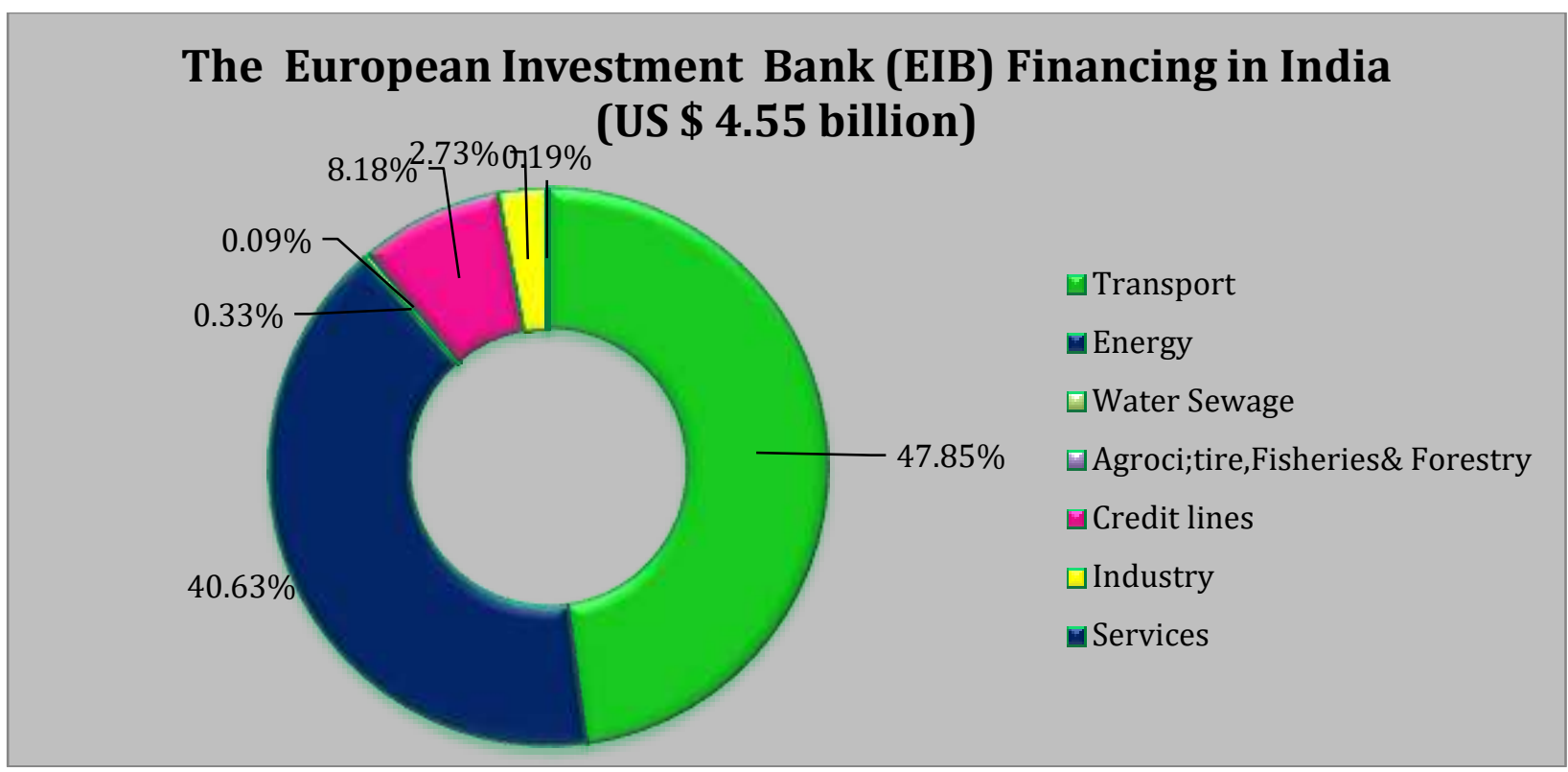

Fig. 3: The European Investment Bank (EIB) Financing in India

From the above graph, it is stated that 4.5 billion US dollars were invested by one of the world's famous financers that is European investment bank not only for climate action but also for microenterprises. They provide finance for various sectors like transport, energy, water, sewage, credit lines, industry services.

Table 11: Amount provided and mobilized by developed countries on Climate Finance

\begin{tabular}{|c|c|}
\hline Year & Amount ( US\$) Billion \\
\hline 2013 & 52.2 \\
\hline 2014 & 61.8 \\
\hline 2015 & 44.6 \\
\hline 2016 & 58.6 \\
\hline 2017 & 71.2 \\
\hline 2017 & 78.6 \\
\hline 2019 & 79.6 \\
\hline 2023 (Goal) & 100 \\
\hline
\end{tabular}

Source: Business India November 2021

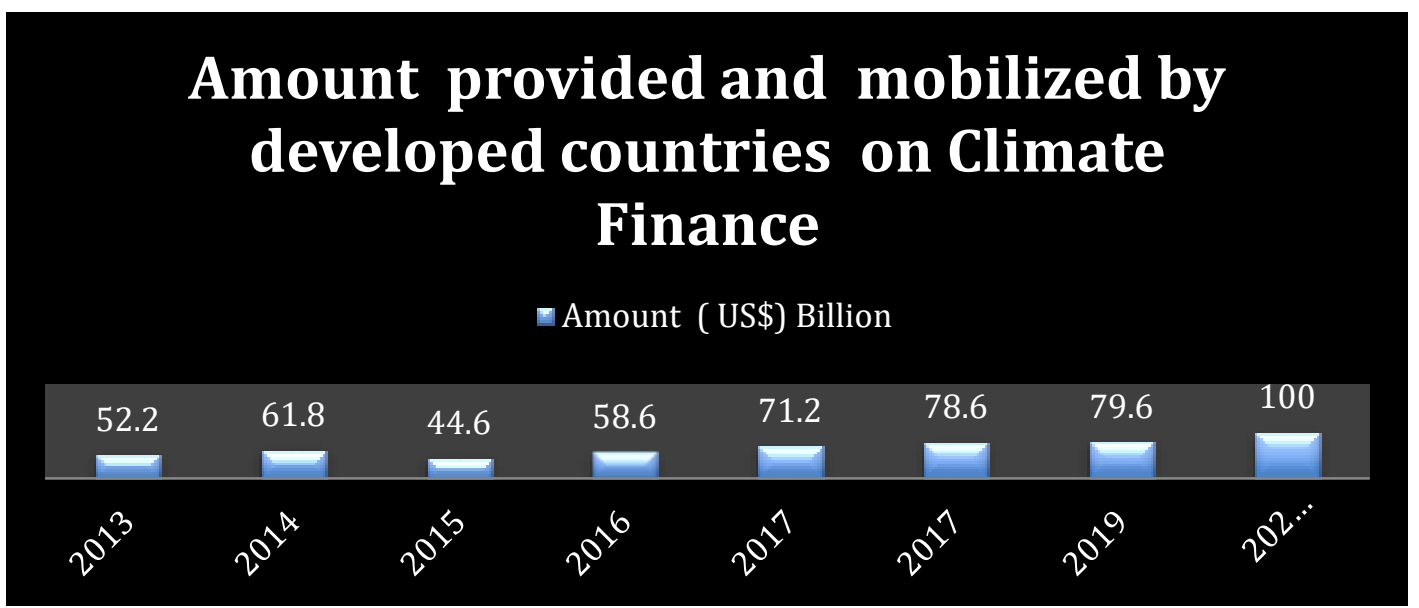

Fig. 4: Amount provided and mobilized by developed countries on Climate Finance

From the above graph, many developed countries finance the growth and development of developing countries and also for climate actions. In 2013, 52.2 us billion-dollar invested by developed countries for climate actions, after that it is increasing from year to year. In 2017 it reached 71.2 us billion dollars and it will reach 100 us billion dollars by 2030 . 
Table 12: Green Bond issuance in India for different sector

\begin{tabular}{|l|l|l|c|}
\hline \multicolumn{1}{|c|}{ Issuer } & \multicolumn{1}{c|}{ Amount } & \multicolumn{1}{c|}{ Sector } & Issued year \\
\hline Yes Bank & INR 10 billion & Energy & 2015 \\
\hline Exim Bank & USD 500 Million & Energy / Transport & 2015 \\
\hline CLP Wind Farms & INR 6 billion & Energy & 2015 \\
\hline IDBI Bank & USD 350 Billion & Energy/Transport/Water & 2015 \\
\hline Hero Future Energies & INR 3 billion & Energy & 2016 \\
\hline PNB Housing Finance & INR 5 Billion & Building & 2016 \\
\hline Axis Bank & USD 500 Million & Energy/Building/Transport & 2016 \\
\hline Renew Power & INR 5 Billion & Energy & 2016 \\
\hline NTPC & INR 20 Billion & Energy & 2016 \\
\hline Greenko & USD 500 Million & Energy & 2016 \\
\hline Renew Power & USD 475Million & Energy & 2017 \\
\hline IREDA & INR 7 Billion & Energy & 2017 \\
\hline Rural Electrification Co & USD 450 Million & Energy/Water/Waste & 2017 \\
\hline Azure Power & USD 500 Million & Energy & 2017 \\
\hline IREDA & INR 19.5 Billion & Energy & 2017 \\
\hline $\begin{array}{l}\text { Indian Railway Finance } \\
\text { Corporation }\end{array}$ & USD 500 Million & Energy & 2017 \\
\hline Renew Power & USD 375 Million & Energy & 2019 \\
\hline Greenko & USD 950 Million & Energy & 2019 \\
\hline Greenko & USD 300 Million & Energy & 2019 \\
\hline Renew power & USD 300 Million & Energy & 2019 \\
\hline Azure power & USD 350 Million & Energy & 2019 \\
\hline State Bank of India & USD 650 Million & Energy & 2019 \\
\hline Adani Green Energy & USD 362 Million & Energy & 2020 \\
\hline Renew power & USD 450 Million & Energy & \\
\hline State Bank of India & USD 100 Million & Energy & \\
\hline Sorce: Gra & & & 20 \\
\hline
\end{tabular}

Source: Green clean guide

Developed countries pledged to provide poor and developing countries annually to fund mitigation and adaptation efforts:

\section{EV- Electric vehicle in India to make green growth}

Electric two-wheelers sold in 2021-1,35,000

Market share $1.1 \%$

Annual manufacturing capacity- 3 million

Estimated annual electric two-wheelers sales by2025-2million

Investment next 3-5years -22,000crores

No of manufacturer- Ather, Ola, Bajaj, TVS, Hero, Bounce, Revolt, Ampere, Okinawa

ESG - Environment, Social, Governance Indian Companies are adhering to ESG norms Indian international has raised \$22 billion (2021) \$18.5 billion (2019) ESG compliant bonds Source: Economic Times

\section{SDTIRE-MODEL FOR MSMES AND COMPANIES SUSTAINABLE DEVELOPMENT :}

With the help of a review of literature and case studies author developed the conceptual model which is to help MSMEs and Companies for Sustainable development. 


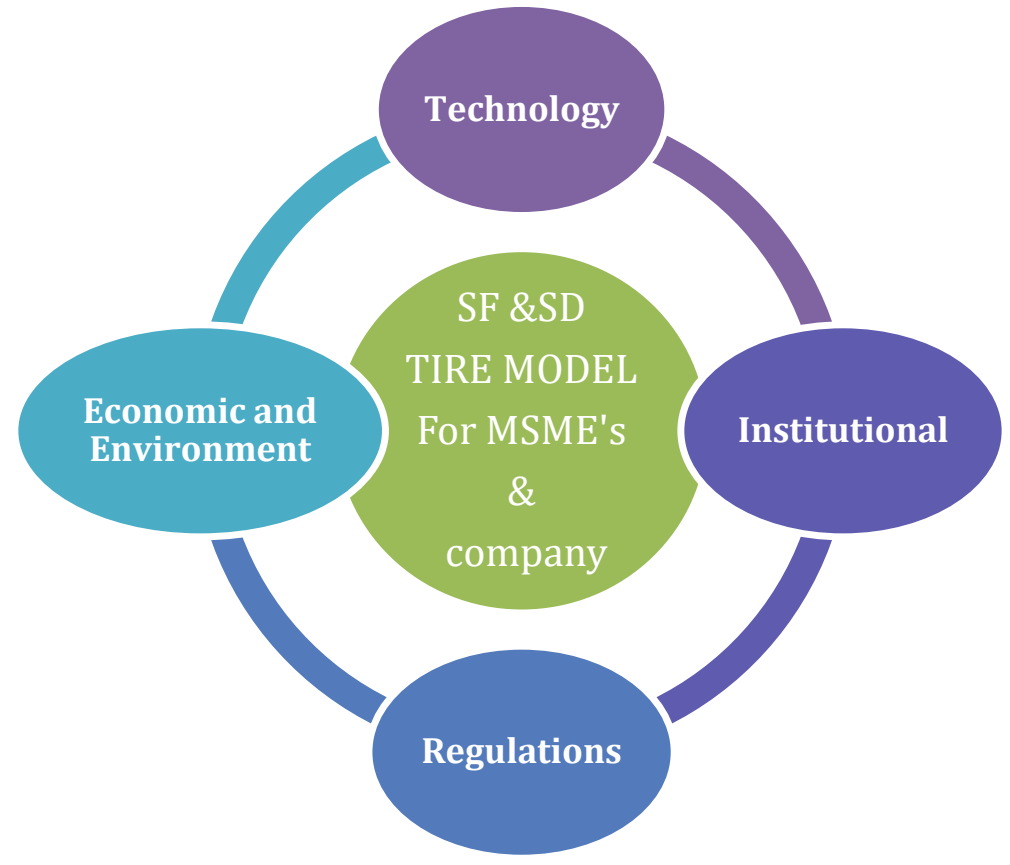

Fig. 5: The Conceptual Model

Technology-Adoption of Digitalization technology AI - Artificial intelligence, Machine learning, IOT - The Internet of Things and Robotics by MSME and Company will transform the green growth. COP26 climate uses artificial intelligence and machine learning to analyse satellite imagery and sensor data for emissions estimation. New age technology and innovation in Reduce, Recycle, Reuse, Recover, Redesign and Remanufacture accelerate sustainability and it has a transformation in mitigation of risk.

Institutional- Funding and finance institution and institution collaboration with International private equity investors, investment banking funds to MSME and Companies in the area of clean energy for safeguarding People, Plant, and Profit, finance are need for mitigation and adaption to reasonable the impacts of a changing climate and inclusive structure of governance.

Regulations-RBI coming up with its guidelines on ESG Compliance and Regulatory push in Raising funds, and resource utilization for achieving a carbon-free nation and governance relating to funds with the public, private regulatory interests of the organization. Regulations and policies can accelerate sustainable growth.

Economic and Environment-Green production and Green consumption by the MSMEs and Companies are essential for improving the quality of life of the present and future creation for sustainable economic growth. It will provide employment opportunities, growth of small industries and Newer sustainable innovations for reaching Socio- economic and environmental solutions [13$15]$.

\section{ABCD ANALYSIS :}

Analysis through advantages, benefits, constraints and disadvantages of the sustainable finance on MSME \&Company, green growth and sustainable developments gives an idea to the beneficiaries a brief. Schemes and programmes offered by the Govt. of India NABARD, SIDBI, RBI and Niti Ayoga are were used for analysis [16 -21].

\subsection{Advantages:}

(1) The global partnership between developing and developed countries and economic governance to encourage mitigation and adaption to climate change.

(2) The multiple organization like International Finance Institution, Banker, Government has more impact in achieving sustainable goals.

(3) RBI has initiated the Regulator framework for ESG disclosure and incorporated environmental impact into commercial lending. 
(4) RBI has included Small renewable energy and social infrastructure projects under priority sectorleading rate.

\subsection{Benefits:}

(1) Climate change poses challenges for both government and Institutions in adopting green policies.

(2) Digital innovations and inventions transforming Indian industries in adopting sustainable and environment-conscious practices.

(3) Government of India commitment to decarbonize and greenery's economy.

(4) Large companies are shifting to green energy, enhancing the opportunities in investment in the green economy.

(5) emerging technologies such as blockchain, GPU, AI, quantum computing can be a game-changer in protecting the environment.

\subsection{Constraints:}

(1) The producer incurred a lot of costs to set up infrastructure and to adopt eco-positive trends.

(2) Easy doing business policy measure to be introduced for converting Fossil fuel to Non -fossil fuel

(3) Institutional participation in ESG Funds are more focused in Western Market as compared to the Indian market due to facilities and expert assistance in green and sustainable development.

(4) The Collaborative push for Capacity building across sectors.

(5) The support and incentive for Eco entrepreneurship will add value in building a green and sustainable future.

(6) The government has made considerable changes in the climate change policy.

(7) The developed countries have not paid their share for "a special climate change Fund, adaptation fund, Least Developed countries fund".

\subsection{Disadvantages:}

(1) For achieving sustainable development different types of finance such as Green asset-backed securities must be used to build technology in the area of RE along with more subsidies.

(2) Financial institutions show more interest in funding sustainable projects to promote prosperity and to secure our future.

(3) ESG regulation is to be framed as having a more positive impact on society, the investment community and the industry.

(4) More collaborative policy measures to be instituted with global stakeholders for achieving a green future.

(5) Through private or public banks government can issue bonds, to tap both domestic and international investors through the world bank and regional development banks.

\section{RECOMMENDATION :}

The government of India has to build separate financial institutions for advising and re-financing the financial intermediaries relating to climate transition risks, due policy, regulation, legal and market changes and which integrate social, environmental and governance for the flow of capital both for financers /investors related to green and environmental change in the area of Clean energy, climate adaptation, sustainable agriculture, Waste management, effective usage of water, Clean transportation and Green buildings for both MSMEs and Corporate in facilitating a low carbon, climate resilient world. To accelerate electrical vehicles, charging units and strengthen the economy and ecology sustainable and cost-effective solution is required.

\section{CONCLUSION :}

More foreign direct investment to be encouraged in waste management, Ecotourism, renewable energy, organic agriculture and development of new-age technology in MSME. Collaboration with global partners plays a vital role in adopting climate change and large companies are shifting to green energy to minimize the negative environmental impact of its activity and regulation to be focused on the green economy. All ESG funds are Sustainable finance are a lucrative opportunity for both investors and corporations and have a positive impact on environmental and Economic growth it is not seen consistent in terms of growth, the government has to initiate the policy measures to adopt green or sustainable finance in the ESG global wave. 


\section{ACKNOWLEDGEMENTS :}

The Author remains indebted to the anonymous referees of the journal, newspaper and respective websites for their highly useful suggestions to develop the quality of the article. The usual disclaimers apply.

\section{REFERENCES :}

[1] Boxenhaum, E., \& Gond, J. P. (2006). Micro-strategies of contextualization: Cross-national transfer of socially responsible investment (Working Paper No. 06-24). Danish Research Unit for Industrial Dynamics, Copenhagen.

Google Scholar $x^{\top}$

[2] Shelly, R., Sharma, T., \& Bawa, S. S. (2020). Role of Micro, Small and Medium Enterprises in Indian Economy. International Journal of Economics and Financial Issues, 10(5), 84 - 91.

Google Scholar X

[3] Renwick, N, Gu, J \& Xue, L (2018). The BRICS and Africa's search for green growth, clean energy and sustainable development. Energy Policy, 120(1), 675-683.

Google Scholar X

[4] Soundarrajan, P., \& Vivek, N. (2016). Green finance for sustainable green economic growth in India. Agricultural Economics, 62(1), 35-44.

Google Scholar $x^{\top}$

[5] Sharma, N. (2015). Constructs and Constraints of MSME in India for Sustainable Development. Asian Journal of Research in Business Economics and Management, 5(4), 8-24.

Google Scholar X

[6] Verma, T. L., \& Nema, D. K. (2019). Role of micro, small and medium enterprises (MSMEs) in achieving sustainable development goals. Int. J. Res. Eng. Appl. Manag, 4(1), 575-582.

Google Scholar X

[7] Acosta, L. A., \& Suresh, S. (2016). Solar energy and inclusive green growth in India: A study of policy impacts on green employment generation in the private sector along the solar energy value chain. Case study prepared for Deutsche Gesellschaftfür internationale Zusammenarbeit (GIZ) GmbH, German Development Institute/ Deutsches Institutfür Entwicklungspolitik(DIE), 2(2), 140.

[8] Pathak, Devendra, Srivastava, Vishal and Sharma, Mohit (2014). Green Finance: How to Beneficiary in Indian Economy. SSRN Journals, 1(1), 1-7.

Google Scholar $\nearrow^{\top}$

[9] Strauß, N. (2021). Framing Sustainable Finance: A Critical Analysis of Op-eds in the Financial Times. International Journal of Business Communication, 1(1) 1-14.

Google Scholar $x^{\top}$

[10] Durrani, A., Rosmin, M., \& Volz, U. (2020). The role of central banks in scaling up sustainable finance-what do monetary authorities in the Asia-Pacific region think?. Journal of Sustainable Finance \& Investment, 10(2), 92-112.

Google Scholar X

[11] Mohd, S., \& Kaushal, V. K. (2018). Green finance: a step towards sustainable development. MUDRA: Journal of Finance and Accounting, 5(1), 59-74.

Google Scholar $\nearrow^{\top}$

[12] Fernandes, C. I., Veiga, P. M., Ferreira, J. J., \& Hughes, M. (2021). Green growth versus economic growth: Do sustainable technology transfer and innovations lead to an imperfect choice?. Business Strategy and the Environment, 30(4), 2021-2037.

Google Scholar X

[13] Withisuphakorn, P., Batra, I., Parameswar, N., \& Dhir, S. (2019). Sustainable development in practice: A case study of L'Oréal. Journal of Business and Retail Management Research, 13 (Special), 35-47. 
Google Scholar $x^{\top}$

[14] Wang, Y., \& Zhi, Q. (2016). The role of green finance in environmental protection: Two aspects of market mechanism and policies. Energy Procedia, 104(1), 311-316.

Google Scholar X'

[15] Dörry, S., \& Schulz, C. (2018). Green financing interrupted. Potential directions for sustainable finance in Luxembourg. Local Environment, 23(7), 717-733.

Google Scholar $X^{\top}$

[16] Aithal, P. S. (2016). Study on ABCD analysis technique for business models, business strategies, operating concepts \& business systems. International Journal in Management and Social Science, 4(1), 95-115.

Google Scholar X

[17] Aithal, P. S., Shailashree, V. T, \& Kumar, P. M. (2016). Application of ABCD Analysis Framework on Private University System in India. International Journal of Management Sciences and Business Research, 5(4), 159-170.

Google Scholar X'

[18] Aithal, P. S. (2017). ABCD Analysis as Research Methodology in Company Case Studies. International Journal of Management, Technology, and Social Sciences (IJMTS), 2(2), 40-54. Google Scholar X'

[19] Aithal, A., \& Aithal, P. S. (2017). ABCD analysis of task shifting-an optimum alternative solution to professional healthcare personnel shortage. International Journal of Health Sciences and Pharmacy (IJHSP), 1(2), 36-51.

Google Scholar X

[20] Aithal, P. S., Shailashree V. T, S., \& Kumar, P. M. (2016). Analysis of ABC Model of Annual Research Productivity using ABCD Framework. International Journal of Current Research and Modern Education (IJCRME), 1(1), 846-858.

Google Scholar X'

[21] Shenoy, V., \& Aithal, P. S. (2017). Quantitative ABCD Analysis of IEDRA Model of Placement Determination. International Journal of Case Studies in Business, IT and Education (IJCSBE), 1(2), 103-113.

Google Scholar X

$* * * * * * * * * *$ 